\title{
Dyskursywizacja ciała na przykładzie doświadczenia niskorosłości kobiet z zespołem Turnera
}

\author{
Kamila Ciepiela \\ Uniwersytet Łódzki \\ kamila.ciepiela@uni.lodz.pl
}

\begin{abstract}
Streszczenie
W ponowoczesności ciało człowieka nie jest prywatna domena jednostki, ale obszarem działania i produktem hegemonicznego dyskursu kulturowego. Wyglad ciała kobiety z zespołem Turnera może znaczaco odbiegać od narzuconego ideału, ponieważ głównym jego symptomem jest niskorosłość. W wyniku suplementacji hormonem wzrostu (GH), może ono osiagnać średni wzrost $w$ danej wspólnocie. W Polsce terapia GH jest dostepna od roku 2000, co oznacza, że kobiety urodzone przed rokiem 1980 jej nie otrzymaty, a więc ich wzrost znaczaco odbiega od średniego $w$ polskim społeczeństwie. W przeprowadzonym badaniu jakościowym, wypowiedzi kobiet z ZT zebrane $w$ wywiadzie pogtębionym, zostały poddane krytycznej analizie dyskursu, która miała wykazać, jak zmienia się pozycja społeczna kobiet wraz ze zmiana wzrostu ciała. $Z$ badania wynika, że ciało kobiet, które nie byty leczone hormonem, jest kategoryzowane jako nienormatywne i jest napiętnowane społecznie, natomiast ciało tych, które przeszły terapie wpisuje się $w$ społeczno-kulturowy schemat cielesności, co przekłada się na ich dobrostan psychospołeczny. Oczekiwania społeczne odzwierciedlone sa w postrzeganiu własnego ciała przez kobiety z ZT i ich działaniach dopasowujacych do normy społecznej.
\end{abstract}

Stowa kluczowe: ciało, dyskurs, syndrom Turnera

Abstract

Discursivisation of the Body on the Example of Women with Turner Syndrome

In post-modernity, the human body is not a private domain of the individual, but the product of hegemonic cultural discourses. Because of short stature, the appearance of the body of a female with Turner syndrome may differ from the socially imposed ideal. As a result of growth hormone supplementation, it can achieve average height in a given community. In Poland, this therapy has been available since 2000, which means that women born before 1980 did not receive it, so their height significantly differs from the average in Polish society. In this study, testimonials of women with TS collected in semi-structured interviews were subjected to critical discourse analysis. The findings reveal that the body of those females with TS who have not been treated with growth hormone is categorized as non-normative and socially stigmatized, while the body of those who have undergone the therapy fits the socio-cultural schema of corporeality, which 
translates into psycho-social well-being of these women. Social expectations are reflected in the perception of their own body by women with TS and their adjustments to the social norm.

Keywords: body, discourse, Turner syndrome

\section{Wstęp}

W ujęciu materialistycznym człowiek jest istotą cielesną, co oznacza, że nie tylko posiada ciało, ale także jest ciałem i każde jego doświadczenie jest zakorzenione w ciele. Wydawać by się mogło, że ciało jest naturalną zmienną istniejącą w przestrzeni społecznej. Jednakże w ponowoczesnym społeczeństwie nie jest ono idiosynkratycznym atrybutem jednostki, ale, jak twierdzi Foucault ([1975] 1998), obszarem działania władzy i produktem relacji polityki/władzy. Społeczeństwo narzuca na ciało siatkę znaczeń, których odrzucenie bądź niespełnienie jest uznawane za wyraz indywidualnej dewiacji.

Klinicznie dystynktywną cechą zespołu Turnera (ZT) jest niskorosłość, przez co ciała kobiet z tą kondycją odbiegają od społeczno-kulturowych schematów cielesności. Interesujące jest zatem jak postrzegają one swoje ciało i jak dopasowują je do wymogów otoczenia. W artykule podejmę lingwistyczno-antropologiczną refleksję nad doświadczaniem nienormatywnej cielesności, manifestowanej w niskorosłości oraz nad sposobami jej dyskursywizacji. Analiza językowa wypowiedzi dorosłych kobiet z ZT ma na celu odkrycie sposobu konceptualizacji ich kondycji.

\section{Charakterystyka zespołu Turnera}

Zespół Turnera (ZT) jest wrodzonym zespołem wad genetycznych objawiających się nieprawidłowościami strukturalnymi chromosomu X. Najczęściej występującym kariotypem jest 45X, co oznacza, że w strukturze brakuje jednego chromosomu X. Brak drugiego chromosomu płciowego może sugerować, że płeć genetyczna noworodka z ZT jest nieokreślona. W praktyce jego fenotyp, a przede wszystkim płeć genitalna (Nowosielski 2010) decydują o kategoryzacji noworodka jako kobiety.

Do najczęściej wymienianych cech charakterystycznych dla ZT należą niskorosłość i dysgenezja gonad prowadząca do bezpłodności. Oprócz tych dwóch głównych objawów w ZT często stwierdza się szereg innych cech dysmorficznych (wady zgryzu, poduszeczkowate obrzęki dłoni i stóp, koślawe łokcie i kolana, płetwiasta szyja, puklerzowata klatka piersiowa, niska linia tylna włosów, włosy „wełniste”), które nie są istotne dla bieżącego artykułu. 
Dwa główne objawy zespołu Turnera stanowią przesłankę do namysłu nad tym jak ten specyficzny profil biologiczny jest odzwierciedlany $\mathrm{w}$ dyskursie publicznym dotyczącym cielesności i kobiecości. W artykule ${ }^{1}$ zostanie poddanych analizie dyskursywnej kilka wypowiedzi dorosłych kobiet na temat ich doświadczeń z ZT. W centrum dociekań badawczych leży konstrukcja i realizacja tożsamości w kontekstach mikro- i makrospołecznych ze szczególnym uwzględnieniem niskorosłości jako prymarnej cechy cielesnej decydującej o pozycji jednostki w społeczeństwie.

\section{Dyskursywizacja wzrostu ciala}

Analiza wywiadów z kobietami z ZT ma na celu wykazanie napięć jakie powstają w momencie zderzenia kapitału biologicznego, tzn., naturalnie niskorosłego ciała z oczekiwaniami społecznymi, które wyznaczają pozycję i role jednostki w społeczeństwie.

Niski wzrost nie jest jednostką chorobową ani czynnikiem zagrażającym życiu człowieka, a jednak pierwszym działaniem w procesie „leczenia” ZT jest suplementacja hormonu wzrostu (GH). W Polsce poddawane są jej niemal wszystkie dziewczynki z ZT od 2000 roku. Terapia, ordynowana najczęściej przez lekarza endokrynologa, rozpoczyna się w dzieciństwie, a więc zgodę na jej wdrożenie i kontrolę nad jej przebiegiem nie sprawuje dziewczynka z ZT, lecz jej opiekunowie. Przyjmowanie GH wiąże się z codziennym reżimem dokonania iniekcji o względnie stałej porze przed snem i z zapewnieniem przechowywania ampułek z GH w odpowiednich warunkach, a to wymaga codziennej dyscypliny oraz konkretnych ograniczeń, np. dziewczynki nie wyjeżdżają na wycieczki z rówieśnikami, muszą odpowiednio wcześniej wrócić do domu z zabawy, itp. (Krawczak 2019).

W ZT hormon wzrostu nie jest konieczny do utrzymania osoby w zdrowiu, a jedynym uzasadnieniem do jego podawania jest dopasowanie wzrostu osoby z ZT do normy społecznokulturowej. Wzrost przestaje być prywatną sprawą, a staje się aspektem ciała, które podlega społecznej kontroli, czyli „,ciało to nie tylko coś co mamy i nie tylko coś fizycznego, co istnieje niezależnie od społeczeństwa. Nasze doświadczenie społeczne oraz normy i wartości grup, do których należymy, wywierają silny wpływ na nasze ciało" (Giddens [2001] 2004: 164).

Z dużym prawdopodobieństwem można zakładać, że niski wzrost nie miałby znaczenia, gdyby nie stanowił on wraz $\mathrm{z}$ proporcjonalnie zbudowanym ciałem normy społecznokulturowej. Osiągnięcie średniego wzrostu w danym społeczeństwie jest szansą na lepsze i

\footnotetext{
${ }^{1}$ Badanie jest współfinansowane ze środków PFRON w ramach konkursu „Niepełnosprawność w naukach humanistycznych". Grant nr BEA/000050/BF/D.
} 
godniejsze życie. Z tej perspektywy „kwestie etyczne takie jak niemożność udzielenia świadomej zgody [...] oraz kwestionowanie sensowności samej terapii, choćby z uwagi na jej długotrwałość i kosztowność [...], odchodzą na drugi plan - w Polsce rzadko, jeśli w ogóle, brane są pod uwagę" (Rajtar 2019: 195).

\subsection{Grupa badawcza}

Oryginalnie w badaniu wzięło udział 10 dorosłych kobiet z ZT rekrutowanych poprzez kontakty prywatne, media społecznościowe oraz zaproszenie zamieszczone na profilu Wielkopolskiego Stowarzyszenia osób z ZT. Do analizy w bieżącym artykule zostały wykorzystane fragmenty wywiadów z sześcioma kobietami z ZT, których profil demograficzny pokrywa się z tym dla badania nadrzędnego.

Kryteriami doboru respondentek był ich wiek ( $>18$ lat) oraz zdiagnozowany ZT. Najmłodsza z kobiet miała lat 19 a najstarsza 53. Mieszkały one w miastach o różnej wielkości w Polsce i pochodziły z rodzin zróżnicowanych pod względem wielkości, zamożności i poziomu wykształcenia. Kobiety prezentowały różny poziom wykształcenia - od ukończonej szkoły podstawowej przez szkołę zawodową dla osób z niepełnosprawnościami fizycznymi po studia magisterskie i doktoranckie. Starsze respondentki były czynne zawodowo, zatrudnione dorywczo bądź na czas określony, albo na rencie. Młodsze były w trakcie studiów bądź zatrudnione na stanowiskach urzędniczych w firmach międzynarodowych lub oświacie zgodnie z profilem ich wykształcenia. Każda z kobiet określiła się jako heteroseksualna. Jedna z nich była w związku małżeńskim, dwie były rozwiedzione i w nowych związkach partnerskich, dwie zaręczone, a pozostałe to singielki planujące założenie rodziny w przyszłości. Dwie z nich, studentki, zamieszkiwały z rodzicami, a pozostałe wiodły samodzielne życie. Imiona kobiet zostały zmienione.

Dla potrzeb obecnego artykułu skupię się na analizie fragmentów 6 wywiadów z kobietami z ZT, z których dwie otrzymały suplementację GH. W wyniku podjętych działań terapeutycznych ich ciała uzyskały odmienny wygląd. Szczególnie drastyczną zmianę można zaobserwować w ich wzroście, tzn. mierzą one obecnie $160 \mathrm{~cm}$. Cztery pozostałe kobiety nie przeszły terapii GH z dwu różnych powodów. Dla dwu z nich suplementacja GH była niedostępna, ponieważ okres ich dojrzewania przypadł przed rokiem 2000, kiedy to terapia GH nie była refundowana w Polsce, a po okresie pokwitania suplementacja GH jest nieefektywna. Te dwie kobiety obecnie mierzą poniżej $140 \mathrm{~cm}$. Dla dwu kolejnych kobiet nie było przesłanek do wdrożenia terapii GH, ponieważ naturalnie osiągnęły średni wzrost dla populacji, tj. $150 \mathrm{~cm}$. 


\subsection{Metodologia}

Badanie empiryczne przedstawione w artykule zostało przeprowadzone techniką wywiadu swobodnego z perspektywy uczestniczącej (Reason, Torbert 2010). Wartością wiedzy uzyskanej w takim badaniu nie jest obiektywizm, ale subiektywne ujęcie znaczeń, do których dążą uczestnicy badania. Analiza wypowiedzi pojawiających się w interakcji odsłania mechanizmy nadawania znaczeń własnym doświadczeniom i powiązania sfery osobistej ze społeczno-kulturową (Chase 2003). W centrum badania znajduje się tekst, który jest traktowany w sposób funkcjonalny, tzn. jego struktura formalna jest integralnie związana z jego użyciem. Jest on także pojmowany szerzej jako dyskurs (van Dijk 1997).

Analizując środki semantyczne, składniowe i tekstowe wykorzystane w procesie konstruowania wypowiedzi, badacz może odkryć ulokowanie bohaterów i relacje fabularne w opowieści i interakcji oraz wnioskować o sposobie ich przeniesienia w dyskurs makrospołeczny.

\subsection{Wzrost jako kapital}

We wszystkich wywiadach z kobietami z ZT pojawiało się zagadnienie niskorosłości i terapii hormonem wzrostu. Bardziej dramatyczne historie były przytaczane przez kobiety powyżej czterdziestego roku życia, które nie otrzymały suplementacji GH i nie przekroczyły granicy 140 cm wzrostu, co marginalizuje je i uwydatnia ich nienormatywność w najprostszych sytuacjach życiowych. Dla przykładu, przed rozpoczęciem wywiadu Maria podeszła do wieszaka w restauracji, zwinęła swoją kurtkę w sztywny rulon i podnosząc do góry zahaczyła o wieszak, a Ewa sama poprosiła mnie o powieszenie płaszcza na wieszaku. Tak prozaiczna czynność staje się problemem społecznym, który wskazuje na nierówność w zaspokajaniu potrzeb życiowych. W innym wywiadzie, Julia dzieliła się radością z nowych mebli w pokoju, które zastąpiły stary segment, z którego niewiele mogła sięgnąć bez drabinki.

Wzrost okazuje się również zasadniczą przyczyną niepowodzeń szkolnych i zawodowych oraz prowadzi do obniżenia jakości życia. W czasie wywiadu Maria mówi:

[z]dawałam sobie sprawę, że nie sięgnę i to było najgorsze (...) żebym miała chociaż 150 to już by było inaczej i pracodawca patrzyłby inaczej (...) szyć nie lubiłam, a ten zawód, co chciałam być, przedszkolanką, to zawsze się śmiałam, że pytaliby: dzieci, gdzie macie swoją panią?

Powyższa wypowiedź wskazuje, że wzrost jest dobrem, którego Maria została pozbawiona. Może ona wprawdzie wchodzić w relacje społeczne (aplikować o pracę; wziąć udział w rozmowie kwalifikacyjnej), jednak nie jest podmiotem sprawczym (Archer 2000), a jedynie 
intencjonalnym, który inicjuje pewne wydarzenia, lecz ich wynik jest poza jej zasięgiem. Kontrolę nad jej położeniem i relacjami przejął deficyt wzrostu i to on jest aktorem społecznym. Maria najpierw opowiada o faktycznych wydarzeniach ze swojego życia, a następnie używa trybu warunkowego, wyrażając hipotetyczne życzenie - żebym miała chociaż $150 \mathrm{~cm}$. Czasownik mieć implikuje posiadanie kapitału, a tryb warunkowy wskazuje, że jest to niemożliwe. Dalsza wypowiedź Marii - pracodawca patrzyłby inaczej - wskazuje, że wzrost jest nie tyle sprawą prywatną co konstruktem społecznym, który powstaje w wyniku ,patrzenia” innych, a „widzialność” narzuca na tego, kto ustawi się w jej polu ograniczenia dominującej władzy (Foucault [1966] 2006). Wątek widzialności pojawia się także w dalszej części historii Marii, która dokonując refleksji krytycznej, przyjmuje perspektywę „patrzącego” i mówi: pytaliby: dzieci, gdzie macie swoja pania. Oznacza to, że nauczycielka jest podobna do dzieci. Poszukiwanie podobieństw jest wg Foucault ([1966] 2006) podstawową operacją w procesie poznania. Kategoryzacja nauczycielki dokonana na podstawie tej jednej tylko cechy fizycznej podlega ugruntowaniu w języku. W ten sposób budowany jest ład, w którym niskorosła nauczycielka należy do tej samej kategorii co jej uczniowie. Foucault ([1966] 2006) twierdzi, że przynależność do kategorii społecznej wyznacza jej członkom role społeczne oraz przewiduje ściśle określone sposoby i środki kontrolowania realizacji ich zadań. Przyporządkowanie nauczycielki i uczniów do jednej kategorii burzy hierarchię i relacje uczeń-nauczyciel, degraduje pozycję nauczycielki i powoduje jej utożsamienie z dzieckiem, co uniemożliwia budowę autorytetu nauczycielki opartego na jej kompetencjach i wiedzy.

Podobną opinię na temat relacji wzrost-autorytet wyraża Łucja, która przeszła terapię GH i obecnie mierzy $160 \mathrm{~cm}$. Łucja jest nauczycielką w szkole podstawowej. W wywiadzie mówi:

[o]statnio do mnie dotarło, że te moje uczennice, dziewięcio- i dziesięciolatki są wzrostu, który prawdopodobnie bym osiągnęła, gdybym nie była leczona, nie wyobrażam sobie jak wyglądałaby moja praca i jak budowałabym autorytet nauczycielki.

Wypowiedź Łucji można zinterpretować, odwołując się do teorii metafory pojęciowej (Lakoff, Johnson 1980), która zakłada podłoże empiryczne wielu odwzorowań metaforycznych wyrażonych w języku. Wielokrotnie przytaczanym przykładem metafory orientacyjnej jest WIĘCEJ TO WYŻEJ. Mierzenie ilości jest rozumiane jako określanie pozycji na osi pionowej, co znajduje bezpośrednie zastosowanie w mierzeniu wzrostu. Uogólnienie tej relacji metonimicznej na całe domeny ilości i pionowości prowadzi do ekstensji metaforycznej WIĘCEJ TO WYŻEJ. Niski wzrost implikuje „mniej”. W zależności od bezpośredniego doświadczenia „mniej” może oznaczać niedobór sił fizycznych, witalnych, wiedzy czy władzy. 
W języku potocznym mówimy o „dorównywaniu komuś”, zatem autorytet poprzez ekstensję metaforyczną może być utożsamiany z wysokim wzrostem. Poza tym Lakoff i Johnson (1980) wymieniają metaforę orientacyjną opartą na doświadczeniach życia codziennego, gdzie DOBRZE TO W GÓRĘ a ŹLE TO W DÓŁ, ZDROWIE TO W GÓRĘ a CHOROBA TO W DÓŁ, SPRAWNY TO W GÓRĘ a NIESPRAWNY TO W DÓŁ, WAŻNY TO W GÓRĘ a NIEWAŻNY TO W DÓŁ, która znajduje swe zastosowanie w budowaniu autorytetu nauczyciela. Nauczyciel przewyższa ucznia wzrostem, a to przez ekstensję metaforyczną oznacza także większą wiedzę, siłę, znaczenie i władzę.

W kontekście instytucji edukacyjnej, nauczycielka pozbawiona biologicznego kapitału w postaci wzrostu traci nie tylko władzę rzeczywistą, ale również symboliczną (Foucault [1971] 2002), czyli tę budowaną przez język. W sytuacji opisanej przez Marię, niewidzialność nauczycielki przekłada się na brak jej słyszalności. Jak mówi Sacks (1972), w każdej diadzie komunikacyjnej słychać jej dwie komplementarne części, tzn. interlokutorów. W sytuacji opisanej przez Marię nie słychać głosu jednej części aparatu kategoryzacji członkostwa (MCD - Sacks 1972), tj. nauczycielki. Pytanie jest skierowane do dzieci w kontekście rzekomej nieobecności nauczycielki, która jest poza widzialnością, ponieważ została przyporządkowana do kategorii dziecko na podstawie jednego kryterium jej cielesności, tj. wzrostu. Jej głos jest głosem dziecka, a nie nauczycielki.

Oprócz możliwości formułowania wypowiedzi i uzupełnienia diady komunikacyjnej, istotnym elementem w interakcji jest sposób formułowania wypowiedzi oraz możliwość jej inicjowania przez interlokutorów. W sytuacji opisanej przez Marię, nauczycielki z ZT w ogóle nie słychać, tzn., straciła ona ,językową władzę przedstawiania myśli” (Foucault [1966] 2006: 55) oraz władzę performatywną, czyli wpływającą na przebieg interakcji i działania pozostałych interlokutorów. Zamiast roli aktora, typowej dla nauczyciela, Maria przyjmuje rolę odbiorcy norm narzucanych sytuacyjnie, które są sprzeczne z ładem systemu edukacji.

Podobny brak widzialności i słyszalności przebija się w opowieści o doświadczeniach $\mathrm{w}$ życiu zawodowym innej kobiety z ZT. Ewa koncentruje się na reakcji pracodawcy:

[g]dybyśmy wiedzieli, że pani taka mała, to wcale byśmy pani nie zapraszali na rozmowę w sprawie pracy.

Przez przytoczenie słów innego narratora, który jest podmiotem grupowym, co wnioskujemy z form predykatywnych: gdybyśmy wiedzieli, byśmy nie zapraszali, narratorka z jednej strony konstruuje obiektywizm sytuacyjny, a z drugiej podkreśla siłę istniejącego ładu społecznego, 
który sytuuje ją jako inną i odbiera jej sprawczość w danej sytuacji. To „większy” decyduje o losie „mniejszego”.

Wzrost jest więc kapitałem biologicznym wzmacniającym szanse jednostki na rynku pracy. W sytuacji braku tej „bardzo mocnej bazy wyjściowej” (Zbyrad 2016: 51), kobieta z ZT nie ma możliwości jej pomnażania, pozbawiona więc zostaje wpływu na kreowanie własnej tożsamości. Ponieważ nie jest w stanie osiągnąć konstruowanego społecznie pożądanego wzorca, staje się, jak mówi Bauman (2003), „odpadem”, a jej wartość przekłada się na jej pozycję na rynku ekonomicznym. Zbyrad twierdzi, że ,[k]alkulacje ekonomiczne pomagają nam zrozumieć dokonujące się w przestrzeni społecznej przydziały miejsca dla ciała ludzkiego. W wyniku czego jedne ciała znajdują się w centrum, inne zaś - na peryferiach przestrzeni społecznej” (2016: 51). Ciało kobiety z ZT, nieleczonej hormonem wzrostu sytuuje ją na peryferiach społecznych.

Pogląd o stygmatyzacji osób niskich jako odstających od normy, powtarza się również w opowieści Olgi, czterdziestotrzyletniej kobiety z ZT, matki dziewięcioletniego syna ${ }^{2}$, która nie była leczona GH, ale mierzy $150 \mathrm{~cm}$. Olga przyznaje, że jej wzrost nie miał znaczącego wpływu na jej życie zawodowe, choć dodaje, że wybierając partnera, poszukiwała wysokiego, ponieważ dwoje takich malutkich nie mieściło się w jej wyobraźni. Odnosząc się jednak do sytuacji syna wyznaje:

[p]owiem jak widzę to u syna (...) jak ja syna widzę na co dzień i ja nie widziałam jego niskorosłości. No jest jaki jest. Idziemy do pediatry, no pod 3 centylem, no odstaje. Ale jak idę do przedszkola i jest jakaś akademia. O kurczę o głowę niższy. No ale co tam wyrośnie. Ale jak Piotrek mi zaczął pod koniec pierwszej klasy mówić, że wytykają i już mu dokuczają, mhm, no to już trzeba coś robić, żeby to poczucie własnej wartości już u niego nie spadło od samego początku kiedy ono się kształtuje, żeby to nie miało odbicia na późniejszy wiek.

W opowieści Olgi powraca zagadnienie budowania poczucia własnej wartości uzależnionego od wyglądu zewnętrznego. Brak kapitału, pomijany przez matkę w życiu prywatnym, nie tylko nie zatarł się w rzeczywistości społecznej, ale wręcz się uwydatnił (Zbyrad 2016). Powiększył się rozdźwięk pomiędzy tym co naturalne i prywatne, a tym co społeczne.

Stygmatyzowanie występuje nie dlatego, że osoba jest w jakiś sposób niepełnosprawna. Raczej oddziałuje to metafora NIESPRAWNY TO W DÓŁ, która jest wynikiem ,patrzenia” innych i wejścia w pole ich widzialności (Foucault [1966] 2006). Odstawanie wzrostem

\footnotetext{
${ }^{2} \mathrm{U}$ ok. 7\% kobiet z ZT zdolności reprodukcyjne są zachowane (Oktay i in. 2016).
} 
deprecjonuje całość osoby, która jest kategoryzowana jako nienormatywna bez względu na jej inne przymioty. Przywodzi to na myśl angielskie przysłowie seeing is believing cytowane dla wykazania prymarności informacji uzyskanych na drodze doświadczenia zmysłowego w stosunku do poznania rozumowego. Widzenie zmysłowe jest pojmowane jako faktyczne, a więc obiektywne, co znajduje odbicie w języku. W rzeczywistości, historia Olgi opiera się na jej „widzeniu syna”, co podkreślone jest w wyrażeniu jak widzę to u syna, a naturalność tego zjawiska podkreśla tautologia no jest jaki jest. Historia jest opowiedziana w czasie teraźniejszym, w trybie oznajmującym, co także wydaje się podkreślać jej faktualność. Dodatkowo, odwołanie się do logosu w postaci medycznego narzędzia pomiarowego (skala centylowa) uwiarygodnia prywatne spostrzeżenia Olgi. Opowiadając o napiętnowaniu syna przez rówieśników, Olga wykorzystuje patos, podkreślając negatywne emocje narastające wokół niskiego wzrostu chłopca. Cała historia opowiedziana jest z perspektywy obserwatora zewnętrznego uwikłanego $\mathrm{w}$ działania wspomagające syna $\mathrm{w}$ dopasowaniu jego cielesności biologicznej do wymagań społecznych. Olga próbuje zbudować kapitał biologiczny, którego jej syn został pozbawiony, co ma wzmocnić jego pozycję społeczną i zachować wysokie poczucie własnej wartości. Dąży ona do zatarcia tego, co indywidualne (jest jaki jest) i rozwinięcia tego, co społeczne (o kurczę, o głowę niższy), aby wzmocnić to, co indywidualne, ale nie cielesne (poczucie własnej wartości).

\subsection{Wzrost jako towar}

Biorąc pod uwagę brak kapitału biologicznego i jego wpływ na jakość życia kobiet z ZT, terapia hormonem wzrostu, której celem jest ufundowanie odpowiedniego kapitału biologicznego, wydaje się mieć głębokie uzasadnienie społeczne. Z pomocą medykamentu ciało nabiera kształtów i proporcji akceptowanych kulturowo. Machura (2011: 50) twierdzi, że „,[e]stetyczne doświadczenie ciała jest warunkiem koniecznym lokowania jednostek na drabinie hierarchii społecznej, [ponieważ] [c]iało stało się narzędziem i kryterium stratyfikacji”. W sytuacji braku kapitału biologicznego, jednostki często decydują się na jego powtórne ukształtowanie. Ciało staje się wielce pożądanym towarem, który można nabyć, wykorzystując dostępne środki finansowe przy jednoczesnym zainwestowaniu czasu i wysiłku fizycznego. W przypadku ich braku, jednostka jest skazana na cielesną nienormatywność i odrzucenie społeczne.

Według Zbyrad (2016: 43), obecnie nie tyle kapitał biologiczny co zasoby finansowe są czynnikiem decydującym o pozycji jednostki w strukturze społecznej, ponieważ „[d]zięki nim można poprawić urodę, odchudzić się, odmłodnieć, a nawet zmienić kolor skóry. Kapitał 
materialny nie tylko ułatwia przekształcanie ciała, ale też wyraźnie dominuje nad kapitałem biologicznym".

Jednak w przypadku kobiet z ZT to nie zasoby finansowe, lecz dostępność terapii GH determinuje ich pozycję społeczną. Kobiety z niedoborem wzrostu sytuowane są na peryferiach społecznych, zaś te, które otrzymały suplementację GH w odpowiednim czasie wyrażają duże zadowolenie $\mathrm{z}$ tego faktu i wskazują na jej pozytywny wpływ na ich samopoczucie i pozycję społeczną, mimo znaczących nakładów czasowych i logistycznych, jakie terapia GH pochłonęła.

Lena, dwudziestosiedmioletnia kobieta z ZT, tak wspomina czas suplementacji:

[j]edyne gdzie było mi ciężej to w życiu towarzyskim na czas brania hormonu wzrostu, bo ja miałam powiedziane, że godzina 20:00, 20:15 i ja mam go wziąć (...) ja tak reagowałam, że o 20:30 ja po prostu spałam; on tak na mnie działał usypiająco, jak jakaś melatonina. Masakra! Więc ja po prostu wiedziałam; ja już nawet nie pytałam rodziców czy mogę. Ja wiedziałam, że nie mogę iść na noc do koleżanki czy jechać na wycieczkę szkolną. Od razu powiedziałam nie, bo wiedziałam, że mam głupią klasę. Tu trzeba nazwać rzeczy po imieniu i że oni by nie zrozumieli, co to znaczy mieć ze sobą igłę, lek, a poza tym takie rzeczy czysto techniczne jak, no jak? Po prostu musiałabym mieć lodówkę. To takie problematyczne dla nastolatków. Ja zawsze miałam wrażenie, że ja byłam zawsze kilka kroków do przodu niż moi rówieśnicy; bo tak jest; tak zostało do tej pory.

W wypowiedzi Leny wybrzmiewają wspomnienia o wyrzeczeniach w trakcie terapii GH. Ich ciężar jest podkreślony poprzez szczegóły okoliczności, które jej towarzyszyły. Wymieniając konkretne godziny podawania hormonu, narratorka podkreśla reżim, jaki został wdrożony w jej życiu codziennym wraz z rozpoczęciem terapii, a wykrzyknik Masakra! nacechuje negatywnie cały proces. Ogólnie jednak wysiłek związany z terapią GH przyniósł wymierne korzyści w sferze psychospołecznej. Lena posiada wysoką samoocenę, która, jak wynika z jej wypowiedzi, wcześniej nie była niska, ale na skutek doświadczeń i wyrzeczeń związanych z terapią jeszcze wzrosła. Porównując swoją osobę z rówieśnikami w przeszłości, Lena oceniała siebie wyżej (ja zawsze miałam wrażenie, że ja byłam zawsze kilka kroków do przodu niż moi rówieśnicy) i przeniosła tę samooceną w teraźniejszość (bo tak jest; tak zostało do tej pory). Lena stwierdza, że reżim terapii przyniósł efekt w postaci potocznie akceptowalnej cielesności tylko dlatego, że ona sama będąc przedmiotem oddziaływań (ja miałam powiedziane), była jednocześnie podmiotem refleksyjnym i racjonalnym (po prostu wiedziałam, zawsze miałam wrażenie), który posiadał odpowiednią wiedzę (ja wiedziałam, że nie mogę iść). 
To uwikłanie ciała w relacje wiedzy i władzy (Foucault [1975] 1998) jest także widoczne w dalszej części wypowiedzi Leny:

[m]oże właśnie przez samodyscyplinę, bo tyłam w oczach, więc ja miałam w domu rygor, ja musiałam ćwiczyć, jeździć na rowerze 20 kilometrów dziennie, za co ja dzisiaj ojcu dziękuję, bo teraz wzięłam się za siebie sama i zrzuciłam 18 kilogramów, jeszcze dyszka do ślubu przede mną, ale gdybym nie była buntownicza i się taty słuchała to tego by w ogóle nie musiało być.

W poprzednim fragmencie Lena kilkakrotnie użyła słów wiedziałam $i$ rozumiałam, racjonalizując wartość terapii. W obecnej wypowiedzi Lena ukazuje siebie jako aktorkę aktywnie realizującą reżim terapii i podtrzymującą jej skutki. Ciało, a właściwie jego niedostatki, które wcześniej były jedynie przedmiotem wiedzy Leny, teraz jest przez nią „ujarzmione” (Foucault [1975] 1998), a wcześniejsze mechanizmy zewnętrznej kontroli ciała (miałam w domu rygor, musiałam ćwiczyć, jeździć na rowerze 20 kilometrów dziennie, za co ja dzisiaj ojcu dziękuję), nie zawsze akceptowane przez podmiot wiedzy (gdybym nie była buntownicza $i$ się taty stuchała), zostały zinternalizowane i przekształciły się w „despotyczne ja" (Rose 1998), które wprowadziło rygorystyczne elementy samodyscypliny (wzięłam się za siebie sama i zrzuciłam 18 kilogramów, jeszcze dyszka do ślubu przede mna), a to z kolei „pozwala uwikłać jednostkę w system relacji i zmusić ją do samokontroli. To już nie władza w całym swym majestacie, ale jednostka sama pilnuje, aby jej zachowanie było odpowiednie. Internalizuje zasady właściwego postępowania i stosuje je nawet w przypadkach, gdy instancja karząca nie jest bezpośrednio obecna” (Erbel 2006: 3).

Lena samodzielnie i z rozmysłem troszczy się o własne ciało, jego kształt, rozmiar i kondycję. Teraz jej działania dyscyplinujące ciało są widzialne (zrzuciłam 18 kilogramów), ponieważ są one wyrazem dbałości o posiadany kapitał (wzięłam się za siebie sama) i jego pomnażanie. Wcześniejsza suplementacja GH była prowadzona w sferze prywatnej poza widzeniem innych, a jej celem było ukrycie deficytu kapitału biologicznego. Obecnie Lena jest jednostką „estetyzująco doświadczającą swoje ciało” (Barański 2005: 323), a więc nie potrzebuje już ukrycia, ponieważ zinternalizowała władzę spojrzenia i teraz pracuje pod kontrolą stróża ulokowanego w jej umyśle (wzięłam się za siebie sama).

Ewolucja w relacji władzy zewnętrznej i władzy wewnętrznej widoczna jest $w$ formach czasowników użytych w kolejnych wypowiedziach. Początkowo Lena jest całkowicie podporządkowana władzy zewnętrznej, co jest wyrażone poprzez pasywizację frazy kauzatywnej miałam powiedziane. Stopniowo Lena internalizuje wymagania tej władzy identyfikowanej z kontekstu jako rodzice - poprzez nie w pełni uświadomioną refleksję (po 
prostu wiedziałam), by w końcu zupełnie świadomie przyjąć je jako własne, co jest wyrażone we frazie zwrotnej wzięłam się za siebie sama, gdzie podmiot zdania jest zarówno aktorem jak i beneficjentem czynności wyrażonych predykatem wziąć się.

Uwikłanie relacji wiedzy i władzy słychać też w wypowiedzi dziewiętnastoletniej Elizy, która nie jest poddawana terapii hormonalnej, ponieważ lekarze po przeprowadzeniu badań stwierdzili, że HTZ powinna być odłożona, natomiast terapii GH Eliza nie wymaga, ponieważ mierzy $160 \mathrm{~cm}$. Eliza nigdy nie była napiętnowana z powodu swojego wyglądu, ale czuje się inna, ponieważ diagnoza ZT zapisana w jej dokumentacji medycznej najpierw została przed nią ukryta, a następnie niewystarczająco wyjaśniona. Eliza mówi:

[w] ogóle wcześniej rodzice powiedzieli mi, że jest taki problem i że mogę nie dojrzewać równo z koleżankami i później przeczytałam; i to było tak, że przeczytałam w bilansie i tam były grupy różnych chorób i właśnie zespół Turnera; poczytałam o tym i stwierdziłam, że tak to się zgadza; ale nie było to jakieś wielkie odkrycie, bo już wcześniej wiedziałam, że coś się dzieje

(...) moja mama mówi do tej pory, że to tak nie do końca, ale jednak ja mam napisane w papierach i jak idę do lekarza i rozmawiamy o tym, więc czekam na nią [HTZ], ponieważ usłyszałam, że mam nie ukończony wiek kostny, a żeby ją rozpocząć musi być ukończony, więc muszę czekać i rosnąć jeszcze.

Przywołując autorytety rodziców (rodzice powiedzieli mi), lekarzy i medycyny, Eliza stwierdza, że nie dostarczyły jej one wystarczającej wiedzy na temat ZT (idę do lekarza i rozmawiamy), a nawet celowo umniejszały znaczenie diagnozy w jej życiu (mama mówi do tej pory, że to tak nie do końca). Mimo podjętych prób samodzielnego zdobycia informacji na temat własnej kondycji (przeczytałam $w$ bilansie; poczytałam o tym) u Elizy nie doszło do wykształcenia samodyscyplinującego, „despotycznego ja”. Nie potrafi ona zapewnić sobie spójności i poczucia własnej wartości swoimi własnymi siłami. Oczekuje natomiast pomocy od ekspertów i poddaje się kontroli zewnętrznej, tj. władzy autorytetów (jak idę do lekarza i rozmawiamy o tym; moja mama mówi do tej pory, że to tak nie do końca), a poczucie niezadowolenia oraz psychiczny i fizyczny dyskomfort nie mobilizują jej do podejmowania działań poznawczych i aktywnego kształtowania swej tożsamości. Eliza jest przekonana, że dzięki wiedzy innych jej ciało zostanie wpasowane w akceptowalny społecznie schemat (musze czekać i rosnać).

Analiza struktury predykatowo-argumentowej wypowiedzi wskazuje na dużą pasywność Elizy w kształtowaniu wyglądu ciała. Głównym źródłem jej wiedzy o kondycji fizycznej są rodzice, lekarze oraz literatura fachowa, co jest wyrażone w formach czasu przeszłego 
czasowników przeczytać i ustyszeć, gdzie argument w pozycji podmiotu jest epistemicznym beneficjentem czynności wyrażonych tymi czasownikami. Eliza zdobywa wiedzę, nie podejmuje zaś działań, które miałyby dopasować wygląd jej ciała do normy społecznej, wierząc, że dokona się to samorzutnie, co sugeruje użyty w wypowiedzi czasownik modalny musieć. Jeśli interpretowany deontycznie, może on wyrażać przekonanie Elizy o słuszności przyjęcia postawy pasywnej, a jeśli interpretowany epistemicznie, może wyrażać przekonanie o faktywności zaprogramowanego genetycznie rozwoju ciała, która jest poza kontrolą władzy zewnętrznej. Takie przekonanie o nieuchronności planu genetycznego zostało zbudowane na podstawie hipotezy zwerbalizowanej przez matkę „mogę nie dojrzewać równo z koleżankami” oraz na podstawie obserwacji ciał rówieśniczek dokonanych przez Elizę (nie było to jakieś wielkie odkrycie, bo już wcześniej wiedziałam, że coś się dzieje). Warto zauważyć, że wszelkie aktywności Elizy mają charakter poznawczy, a nie behawioralny. Eliza zdobywa wiedzę o malformacjach ciała i stopniu jego nienormatywności, co implikuje istnienie przyjętego społecznie wzorca, którego jej ciało nie spełnia.

Podobne uwikłanie wiedzy i władzy autorytetu widoczne jest w działaniach Olgi ukierunkowanych na zmianę cielesności jej syna:

[j]a mu mówię, ale patrz powiedz mu, że dostajesz, znaczy nie, (...) bo nie chodzi o to przecież żeby się chwalić, ale jeszcze trochę i będzie dużo lepiej. Tak podbudowuję go tym komentarzem moim (...) żeby miał to poczucie, że ta szklanka do połowy jest pełna a nie pusta.

Olga, podobnie jak rodzice Elizy, kształtuje w synu odpowiednią postawę w stosunku do jego własnego ciała poprzez perswazję werbalną popartą widocznymi pozytywnymi zmianami wyglądu ciała spowodowanymi suplementacją GH. Poprzez medykalizację (hormon wzrostu) i „poprzez umiejętne kierownictwo” (ja mu mówię, ale patrz; tak podbudowuje go tym komentarzem moim) zostanie ukształtowany człowiek, „który zinternalizował zewnętrzną dyscyplinę i zasady”, człowiek „wolny od przypadkowych, popędliwych, nieprzemyślanych zachowań” (Majer 2016: 78), człowiek, który będzie wiedział jak prawidłowo napełnić swoje ciało, aby zostało zaakceptowane przez innych. Metafora pojęciowa CIAŁO TO KONTENER wyrażona za pomocą ta szklanka do połowy jest petna a nie pusta wskazuje, że Olga podobnie jak rówieśnicy syna widzi, że natura nie obdarzyła go odpowiednim kapitałem, ale Olga wie, że można go zdobyć inwestując środki finansowe, wysiłek i czas. Dla Olgi wzrost jest towarem, który można nabyć i dzięki temu sfabrykować ciało, które będzie akceptowane przez otoczenie.

Zupełnie przeciwny stosunek do wyglądu ciała prezentowali rodzice Ewy - dziś pięćdziesięciotrzyletniej kobiety z ZT, która tak relacjonuje czas diagnozy i terapię: 
[z]robili badania i zaczęli u mnie podejrzewać zespół Turnera i wysłali mnie do Warszawy do CZD; no i tak wszystko zbadali ten nadgarstek te wszystkie badania genetyczne no i się okazało, że zespół Turnera mam

o hormonie wzrostu to dopiero zaczęto wspominać (...)

mama to się nawet pytała czy nie można jakiś taki hormon wzrostu to ten, to lekarka z CZD powiedziała niech se pani jedzie do Ameryki kupić (...)

no i w sumie później nic nie było robione, bo, prawdę mówiąc mój ojciec zabronił mnie leczyć, a mama oczywiście słuchała (...)

chciał pokazać kto w domu rządzi, prawdę mówiąc to była i przemoc fizyczna i psychiczna, to była milicja; on był milicjantem (...)

nawet praktycznie nie miałam pojęcia o tej chorobie, co to jest, bo nie było żadnych rozmów ani nic z moimi rodzicami; ja myślałam, że to tylko wzrost i mówię mojej mamie, że ja się źle czuję po tych tabletkach; a to nie bierz (naśladuje głos mamy) (...) to ja nie brałam, myślałam niepotrzebne no nie. Później po latach wyszło, że miałam w CZD zlecenie na leczenie za granicą, w Szwecji czy gdzieś, ale oczywiście nawet mi nie powiedzieli o tym (...) no tak rodzice; no ojciec zabronił leczyć i to tak wyszło właśnie ani leczenia ani renty, nie mam nic.

W wypowiedzi Ewy słychać dominację otoczenia i jego ogromny wpływ na jej obecną sytuację. Diagnoza została postawiona przez siły medyczne, o których Ewa mówi w trzeciej osobie liczby mnogiej (zrobili badania i zaczęli u mnie podejrzewać; zbadali), a o niepodejmowaniu terapii GH zadecydował ojciec, który posiadał wiedzę na temat kondycji córki i możliwości terapeutycznych. Z wywiadu z Ewą wynika, że ojciec traktował ją jako osobę „nienormalną”, niewartą terapii. $Z$ decyzją ojca zgodziła się matka, która nigdy nie przeciwstawiała się woli męża. Ewa wspomina, że możliwości medyczne w Polce nie były wielkie w tamtym czasie, ale w innych krajach prowadzono już terapię GH. Relacjonując rozmowę matki z lekarką, Ewa cytuje słowa tej drugiej: niech se pani jedzie do Ameryki kupić, które dowodzą, że poza Polską terapia była dostępna. W przytoczonych słowach pojawia się Ameryka jako metafora bogatego życia, wysokiego rozwoju gospodarczego, społecznego i zaawansowania technologicznego, w którym osoby z ZT miały możliwość terapii GH. Ponieważ w tamtych czasach Ewa była pozbawiona wiedzy na temat swojej kondycji, a władza nie ujawniała tych informacji, Ewa zachowywała się zgodnie $\mathrm{z}$ jej nakazami (a to nie bierz, to ja nie brałam, myślałam niepotrzebne). Konsekwencje braku wiedzy i władzy w przeszłości oraz postawa rodziców 
trwale wykluczyły Ewę z kategorii „normalnych” członków społeczeństwa (ani leczenia ani renty, nie mam nic). Jej niskorosłość jest deficytem, który zdeterminował jej życie osobiste i zawodowe. Mimo podejmowanych wysiłków prowadzących do zdobycia wiedzy (ukończenie studiów wyższych, woluntarystyczna działalność w organizacjach charytatywnych), Ewa nie jest w stanie zmienić swej peryferyjnej pozycji społecznej.

Analiza lingwistyczna potwierdza silny wpływ otoczenia i narzucenie pewnego systemu wartości, które są poza zasięgiem Ewy. O służbie zdrowia w momencie diagnozy Ewa mówi w trzeciej osobie liczby mnogiej, co jest logiczne, ponieważ odnosi się do pewnej procedury biomedycznej wykonywanej standardowo w określonej populacji. Z kolei agensami decydującymi o podjęciu terapii są konkretne osoby: matka, lekarka i ojciec, zaś Ewa jest patiensem. Wszystkie instancje traktują Ewę jako ,inną”, co implikuje istnienie pewnej normy, której ciało Ewy nie spełnia, jednak żadna instancja nie jest zainteresowana jego dopasowaniem do tejże normy. Konsekwencje braku działań ze strony władzy (agensów) u progu życia Ewy widoczne są w całym jej późniejszym życiu (nie mam nic).

W dalszej wypowiedzi Ewa wspomina pracodawcę, który bezpośrednio odniósł się do jej niskiego wzrostu (gdybyśmy wiedzieli, że pani taka mała to byśmy pani w ogóle nie zapraszali), uzasadniając odrzucenie jej kandydatury na oferowane stanowisko pracy biurowej. W trakcie wywiadu, Ewa kreuje jednak wizerunek osoby wykształconej, o szerokiej wiedzy w różnych dziedzinach życia, szczególnie tej dotyczącej ZT oraz praw osób niepełnosprawnych. Jej wypowiedzi są precyzyjne, skupione bardziej na faktach niż na wyrażaniu opinii (wszystko zbadali ten nadgarstek te wszystkie badania genetyczne; mój ojciec zabronit mnie leczyć; była i przemoc fizyczna i psychiczna; bo nie było żadnych rozmów ani nic z moimi rodzicami). Obecnie Ewa wciąż podlega kontroli zewnętrznej, która jest bliżej niezdefiniowaną siłą decyzyjną która pozycjonuje ją na peryferiach społeczeństwa. W zmedykalizowanej kulturze Ewa, pozbawiona kapitału wzrostu, nie może stać się konsumentem towaru oferowanego osobom z ZT, a przez to nie może zapewnić sobie osiągnięcia ,adekwatnej” cielesności będącej wyznacznikiem jednostkowej tożsamości.

\section{Wnioski}

Analiza środków składniowych i tekstowych w wypowiedziach kobiet z ZT wskazuje, że ludzkie ciało stało się produktem życia zbiorowego, który działa jak narzędzie dyscyplinowania jednostek, a niskorosłość jest prymarną cechą cielesną decydującą o pozycji jednostki w społeczeństwie. Kobiety z ZT, które nie otrzymały suplementacji GH odczuwają silną 
stygmatyzację zarówno w kontaktach werbalnych jak i niewerbalnych, w życiu prywatnym i społecznym. W ich wypowiedziach przeważają struktury predykatowo-argumentowe, w których to władza zewnętrzna jest agensem, a kobiety podlegają jej oddziaływaniu. Te kobiety, które otrzymały suplementację GH i osiągnęły akceptowalny społecznie wzrost realizują się w życiu prywatnym i zawodowym i uchodząc za „normalnych” członków społeczeństwa, sytuują się w roli aktorów, którzy wydają się kontrolować procesy mentalne, fizykalne i społeczne, dzięki czemu ich ciała przybierają społecznie akceptowalny wygląd. Faktycznie jednak, to norma jest czynnikiem determinującym ich działania.

Analiza środków semantycznych, w tym metafory pojęciowej, ujawnia napięcia, jakie powstają w momencie zderzenia kapitału biologicznego, tzn., naturalnie niskorosłego ciała z oczekiwaniami społecznymi, które wyznaczają pozycję i role jednostki w społeczeństwie. Jednostki z ograniczonym kapitałem biologicznym, tak jak kobiety z ZT, mogą go odbudować dzięki postępom medycyny, jest to jednak uzależnione od dostępności środków i procedur medycznych oraz od zasobów finansowych. Jednostki, które z różnych powodów nie są w stanie zakupić towaru, który uzupełni ich kapitał biologiczny są kategoryzowane jako przynależące do peryferii społecznych bądź jako dewianci.

Foucaultowska dyscyplina cielesna ma więc dwojaki cel. Po pierwsze pomaga zbudować autoportret akceptowalny przez samą kobietę z ZT, a po drugie uczynić ją „niewidzialną” społecznie.

\section{Podziękowania/ Informacje dodatkowe}

Składam serdeczne podziękowania wszystkim kobietom, które zgodziły się wziąć udział w badaniu, co przyczyniło się do powstania tego artykułu i pozwoliło na upowszechnienie problemów, z jakimi na co dzień borykają się kobiety z zespołem Turnera.

\section{Bibliografia}

Archer, Margaret (2000) Being Human: The Problem of Agency. Cambridge: Cambridge University Press.

Barański, Jarosław (2005) „Ciało i zdrowie w ujęciu socjoestetycznym”. [W:] Włodzimierz Piątkowski, Włodzimierz A. Brodniak (red.) Zdrowie $i$ choroba. Perspektywa socjologiczna. Tyczyn: WSSP w Tyczynie; 323-336.

Bauman, Zygmunt (2003) Razem osobno. Kraków: Wydawnictwo Literackie. 
Chase, Susan (2003) „Learning to Listen. Narrative Principles in a Qualitative Research Methods Course". [W:] Ruthellen Josselson, Amia Lieblich, Dan McAdams (red.), Up Close and Personal: The Teaching and Learning of Narrative Research. Washington, DC.: American Psychological Association; 79-99.

Dijk, van Teun (1997) „Discourse as Interaction in Society”. [W:] Teun. van Dijk (red.) Discourse as Social Interaction. London: Sage; 1-38.

Erbel, Joanna (2006) „Zarządzanie cielesnością: O kontrolowaniu materialności kobiecego ciała". [pobrane z http://www.ekologiasztuka.pl/pdf/f0009erbel.pdf. Data ostatniego dostępu 27.02.2020].

Foucault, Michel ([1975] 1998) Nadzorować i karać. [Surveiller et punir. Paris: Gallimard]. (tłum.) Tadeusz Komendant. Warszawa: Fundacja Aletheia.

Foucault, Michel ([1971] 2002) Porzadek dyskursu. [L'ordre du discurs. Paris: Gallimard]. (tłum.) Michał Kozłowski. Gdańsk: Wydawnictwo Słowo/obraz terytoria.

Foucault, Michel ([1966] 2006) Stowa i rzeczy. Archeologia nauk humanistycznych. [Les mots et les choses. Une archéologie des sciences humaines. Paris: Gallimard]. (thum.) Tadeusz Komendant i Anna Tatarkiewicz. Gdańsk: Wydawnictwo Słowo/obraz terytoria.

Giddens, Anthony ([2001] 2004) Socjologia. [Sociology. Cambridge: Polity] (thum.) Alina Szulżycka. Warszawa: Wydawnictwo Naukowe PWN.

Krawczak, Anna (2019) „Calineczki. O społecznych konstrukcjach zespołu Turnera”. Etnografia. Praktyki, Teorie, Doświadczenia, $\quad 5 ; \quad 129-143$. https://doi.org/10.26881/etno.2019.5.06.

Lakoff, George, Mark Johnson (1980) Metaphors We Live By. Chicago: The University of Chicago Press.

Majer, Anna (2016) Dyskurs dyscyplinowania męskiego ciała w wybranych tekstach kultury popularnej. Gdańsk: Wydawnictwo Naukowe Katedra.

Machura, Anna (2011) „Ciało jako kapitał. Medykalizacja życia społecznego”. Zeszyty Naukowe Ruchu Studenckiego 1; 50-60.

Nowosielski, Krzysztof (2010) „Identyfikacja i rola płciowa”. [W:] Zbigniew Lew-Starowicz, Violetta Skrzypulec (red.) Podstawy seksuologii. Warszawa: PZWL; 266-273.

Oktay, Kutluk (2016) „Fertility Preservation in Women with Turner Syndrome. A Comprehensive Review and Practical Guidelines”. Journal of Pediatric and Adolescent Gynecology 29 (5); 409-416.

Rajtar, Małgorzata (2019) „Bioetyka i technologie wzmacniania ludzkiego ciała w kontekście doświadczeń kobiet z zespołem Turnera”. [W:] Ewa. Maciejewska-Mroczek, Magdalena. 
Radkowska-Walkowicz, Maria Reimann (red.) Zespół Turnera. Głosy i doświadczenia. Warszawa: Oficyna Naukowa; 171-197.

Reason, Peter, William R. Torbert (2010) „Zwrot działaniowy. Ku transformacyjnej nauce społecznej”. [W:] Hana Červinkowá, Bogusława Dorota Gołębniak (red.) Badania w działaniu. Pedagogika i antropologia zaangażowane. Wrocław: Wydawnictwo Naukowe DSW; 117-152.

Rose, Nikolas (1998) Inventing our Selves. Psychology, Power and Personhood. Cambridge: Cambridge University Press.

Sacks, Harvey (1972) „An Initial Investigation of the Usability of Conversational Data for Doing Sociology”. [W:] David Sudnow (red.) Studies in Social Interaction. New York: Free Press; $31-74$.

Zbyrad, Teresa (2016) „Ciała konstruowane społecznie z dyskryminacją w tle: współczesne problemy socjologii ciała”. Społeczeństwo i Rodzina 48 (3); 41-57. 